\title{
OPTIMIZATION MODEL FOR MATERIALS EXPEDITION: AN APLICATION IN A RETAIL CHAIN STORE
}

\author{
Rogério Santos Cruz \\ Federal Institute of São Paulo - Suzano Campus, Brazil \\ E-mail: rogerio.alisp@gmail.com \\ Elder Rodrigues Viana \\ Federal Institute of São Paulo - Suzano Campus, Brazil \\ E-mail: er.vianna@yahoo.com.br \\ Adriano Maniçoba da Silva \\ Federal Institute of São Paulo - Suzano Campus, Brazil \\ E-mail: adrianoms@ifsp.edu.br \\ Alcir das Neves Gomes \\ Federal Institute of São Paulo - Suzano Campus, Brazil \\ E-mail: alcir.gomes@ifsp.edu.br \\ Submission: $31 / 03 / 2016$ \\ Accept: 31/03/2016
}

\section{ABSTRACT}

In several companies, transportation costs are most part logistics costs. In this context, the appropriate distribution planning figures as a strategic activity in the generation of competitiveness. Previous studies that analyzed the transportation problem do not consider the role of the expedition in their models. This research investigated a transportation problem considering the expedition of goods. A midsize retailer located in the $A B C$ region of Sao Paulo was used to conduct a case study. In addition to documentary data, interviews were conducted with professionals involved in the expedition operation. The results indicated that the company could optimize their expedition by considering the changes proposed in this study. We conclude that the expedition is an important activity in the analysis of a transport model.

Keywords: expedition, linear programming, retailing. 


\section{INTRODUCTION}

In the competitive context in which companies are inserted, the decision process does not admit failure in solving problems or results fall short of those achieved by competition. In this context, it is present the importance of preparing managers assuring they know the tools and techniques used to make decisions and that they are able to realize the analytical methods implementation such as linear programming (LP) for solving complex problems, thus optimizing the results of organizations (BARCELOS, et al., 2012).

Also according to Barcelos et al. (2012), PL is a technique for decisionmaking, with problems mathematical modeling, seeking optimal solutions applied to business reality. The manager, as decision maker, may be beneficiary with the information extracted by LP results.

The PL can also be used in planning public and private operations, in resource allocation systems, arrangement of jobs, mathematical programming and humanitarian aid, with adequate grip for application in practical and real problems (KARSU; MORTON, 2015).

Previous studies have used linear programming in investigating transportation problems in receiving and distribution operations (OLIVEIRA, 2014), in the decision to buy or sell used vehicles (COSTA, et al., 2014), and it was also when could be noted the role of materials logistics (RONCARI; DELMANTO JUNIOR, 2012). Despite important role in the set of activities involving a supply chain, the expedition has not been included in the models that investigate transportation problems optimization. From this gap, this research sets out the following problem question: How to model expedition in the context of optimizing a transportation problem?

In this sense, the aim of this study is to propose an optimization model of transportation operations to include in his analysis the shipping activity. In order to operationalize the research, a case study was conducted on a midsize retailer located in the great $A B C / S P$ region, aiming to verify the usefulness of the proposed model.

Besides the theoretical relevance, it is appropriate to conduct this research due to the fact that transportation operations, when not properly optimized, increase significantly the way logistics costs influence the operation speed. This can cause a 
DOI: 10.14807/ijmp.v7i5.454

decrease to the customer service levels and increase the product cost. It is important to note that the existence of transportation problems also entails higher costs due to inventory and storage.

According to the ILOS Panorama study (2014), expenditure with logistics in companies, considering only the transportation, inventory and storage costs, they represent $8.7 \%$ of net revenue. Thus, the optimization of transportation operations with the inclusion of shipping in the model becomes an important issue in order to obtain competitive advantage in the market. The next section presents the theoretical framework.

\section{THEORETICAL FRAMEWORK}

\subsection{Operational research models and linear programming}

Knowledge and optimization of the production process is essential to increase efficiency and keep the company competitive in the market. In production environments, mathematical models are used for accurate processes analysis of and decision-making. Decisions are made at the most strategic, tactical and operational levels, and it means that choosing a choice between alternative solutions, implies in influencing corporate performance. (RAYMUNDO; GONÇALVES; RIBEIRO, 2015).

Andrade (2009) explains that the current approach, in recent decades, with the problems analysis using linear programming, considers the quantitative focus on the operational research, which is the recognition that the quantitative approach to problems provides a reasoning structure and analysis which allow to develop a systemic view of the process. This approach can also serve as a support to decisionmakers.

The idea of using models to solve problems and make decisions is not relatively new and it is not tied exclusively to the use of computers. These models can be simply structured, similarly to mental models, until the use of mathematical methods, commonly used when only intuition or experience does not provide enough information for decision making (RAGSDALE, 2007).

Mathematical models have advantages over a verbal description of the problem. One is that the mathematical model describes the problem much more concisely (HILLIER; LIEBERMAN, 2010). According to Arenales et al. (2007), 
DOI: 10.14807/ijmp.v7i5.454

mathematical optimization models are strictly related to the study of operational research, as this area of study is not only used to define the ideas and processes of decision problems, but also to optimize numerical systems that use data in the models.

Once the mathematical model is consisted, it is possible to obtain an optimal solution to the problem. Several mathematical methods are in constant development. The software that automated these models are important tools for solving complex problems. Among the specific software for linear programming, it is worth mentioning the following: Solver Excel $\circledast$, which is a tool with simple commands, but able to provide accurate results for more limited models; the LINDO® - Linear Discrete Optimizer; and CPLEX®, these two last ones used for more complex problems (MARINS, 2011).

Mathematical models of problem solving are simplified representations of reality. The resolution of these problems is divided into five stages: problem formulation; construction of the mathematical model; solution obtaining; solution testing; and implementation (MARINS, 2011).

Marins (2011) also states that the use of mathematical models in decision making allows to describe the essence of the problem and to identify what are the relationships among the studied variables, their relevant data, and the most important variables. Operational research can be used to solve several areas problems. The most common problems can be:

- Linear Programming: production mix, raw materials mix, investment base, vehicle routing;

- Network Models: transportation routes, goods distribution and transportation, project monitoring;

- Queuing Theory: traffic congestion, hospital operations, allocation of service teams.

Lachtermacher (2007) clarifies that the Operational Research (OR) is an area of study that integrates computers, statistics and mathematics to solve real problems applied to businesses under three main objectives: to convert data into meaningful 
information; to support the decision-making process; and to create useful computer systems to non-technical users.

The OR is closely related to the decision-making process within companies that use it, especially when it comes to raising a problem or identifying an opportunity with the appropriate action lines (LACHTERMACHER, 2007). Basically, modeling a problem occurs through: physical models, analogous models and mathematical or symbolic models.

Mathematical models are the most commonly used in management analyses involving the issue of distribution of limited resources among the company's activities (VANDERBEI, 2008).

Within the mathematical programming, there is a subdivision that will depend on the type of functions used in functions-objective and constraints. In linear programming, all of the functions-objective and constraints are represented by linear functions. On the other hand, regarding the nonlinear programming, at least one of the functions-objective and/or constraints are represented by nonlinear functions (LACHTERMACHER, 2007).

As mentioned earlier, the linear programming is a mathematical technique that aims to find the best solution to problems that have their models represented by linear expressions. In many ways, linear programming is one of the most used Operational Research techniques when involving optimization problems. In this sense, its modeling seeks the efficient distribution of limited resources, targeting to meet a specific goal, in general, to maximize profits or minimize costs (ANDERSON; SWEENEY; WILLIAMS, 2007). In the context of linear programming, the next section specifies the transportation problems.

\subsection{Transportation problems}

The transportation problem is considered the most representative of linear programming problems. It is of wide practical application and has been studied by many researchers, although it was Danzig $(1953 ;$ 1963) the first to establish its formulation in LP and to propose a systematic resolution method, as well as being the creator of the simplex method (CANAVARRO, 2005). 
DOI: $10.14807 /$ ijmp.v7i5.454

Charges urban transportation is a fundamental activity for cities economic development. However, adverse effects on the environment are observed, such as the commitment of vehicular traffic conditions, high energy consumption and pollutants emission (CASTRO, 2013).

In recent years, many studies have been conducted in regards to traffic levels, and its impact in large cities. These focus mainly on the analysis of public transportation and on private vehicles with relatively little concern about urbanely transporting charges (BROWNE et al., 2005).

The Vehicle Routing Problem (VRP) is also an issue of strategic importance and difficult computational solution (LAPORTE, 1992). So, it has been studied for several decades by several researchers around the world. A route is a sequence of delivery and/or collecting points that the vehicle must cover neatly, starting and ending in a warehouse. A Vehicle Routing Problem (VRP) basically consists in establishing and organizing efficient routes for vehicles carrying out the distribution of goods, then minimizing costs. By featuring a fleet of vehicles, identical or not, it is desired to meet a set of $n$ customers, each of them with a specific demand (PINHEIRO, 2015).

Based on the concepts reviewed in section 2, and on the problem outlined in the introduction, this study sets out the following research hypothesis:

\section{H1: The expedition model making use of linear programming allows to increase a company's operations efficiency.}

With the hypothesis highlighted, the next section deals with the methodology.

\section{METHODOLOGY}

This study was conducted in a distribution center - CD of a midsize retailer located in ABC Paulista region, which supplies 20 stores nearby. For the execution of this study, interviews were carried out with professionals involved in the expedition operation, as well as field visits to observe the operations at the distribution center and, in addition, documents that contributed to the understanding of the characteristics of Company operation were assessed. The data obtained in the research have qualitative origin (interviews) and quantitative origin (data operation) too. 
DOI: $10.14807 /$ ijmp.v7i5.454

In total, there were six field visits. The first visit aimed an overview of the company, where it was possible to identify its market strategy. The second visit, aimed to recognize the chain distribution center operations deeply. In the third, fourth, fifth and sixth visits, the expedition operations were studied, once it is this study object, stage in which there was a comprehension about the way the operation is performed, what its characteristics are, its strengths and weaknesses. Then, individual interviews with important people in expedition operation were held, which they are, the Logistics Operator, the charge and expedition Leader and the Supply Chain Manager. The opinion of each of them was asked in order to confront the information obtained in interviews with what was seen on field visits.

Next, operation documents were analyzed targeting to measure important indexes to sustain the information obtained from the interviews with professionals and the conclusions taken from field visits. At last, the data obtained through field visits, interviews and specific documents were triangulated with the intension to validate data obtained throughout the case study stages (YIN, 2010). The next section presents results analysis.

\section{RESULTS ANALYSIS}

\subsection{Description of the company}

The case study was conducted in a food distributor that has 20 stores and a Distribution Center (DC) in the ABC Paulista region. The DC has 12 vehicles to meet the shops demand, 10 trucks and 2 van trucks, with capabilities to 14 and 12 pallets respectively. The DC demand is composed by pallets of household appliances and electrical portable, cross-docking and picking. Cross-docking goods have slowmoving turnover, unlike the picking products, which have constant output and high inventory turnover. Finally, household appliances and electro portable that comes from a sector called CD2.

It was found that, in the company, there was no method to determine which stores would be met first. Empirically, the employees stipulated intuitively what stores would be served for first, because the separation of goods was performed 24 hours a day, in three shifts, while the expedition only operated from 8 a.m. to 4:20 p.m. from Monday to Saturday. 
DOI: $10.14807 /$ ijmp.v7i5.454

In this scenario, a bottleneck was identified due to the fact that the expedition could not send all the pallets that were separated, so every day in the morning, before expedition operation started, there was an average of 415 pallets to be sent to the shops, and there was no plan of how these pallets would be sent. In the operational system the company worked, as the charges came, the expedition sent them. From this context, the next section deals with the problem modeling.

\subsection{Problem modeling}

It is proposed in this section, the development of a model for expedition planning, where the pallets to be sent at the beginning of the operation would already have defined destination, turning the process more systematic, considering that each vehicle would have a specific demand to serve on.

The total time of daily operation was defined through Equation 1:

$$
T T O=Q v(J t-H a)
$$

Where:

TTO : Total time of operation

Qv : Quantity of vehicles

$J t$ : Working hours

Ha : Lunch time

The cycle time for each store was obtained through Equation 2::

$$
T C_{l}=T_{c}+T_{i}+T_{d}+T_{r}
$$

Onde:

$T C_{\text {l: }}$ Store cycle time

$T_{c}$ : Charging time

$T_{i}$ : Coming time

$T_{d}$ : Discharging time

$T_{r}$ : Returning time 
DOI: $10.14807 /$ ijmp.v7i5.454

The store cycle time measures how many minutes each vehicle takes to leave since goods charging, from the DC, get to the store, discharge and return. Thus, it has as calculation the sum of times: loading; coming; discharging and returning.

After obtaining the cycle time and the total time of operation it was carried the expedition problem modeling using SOLVER to obtain a expedition programming which could maximize the amount of pallets sent to stores. Therefore, it was modeled to function objective shown in Equation 3:

$$
\operatorname{Max} \sum_{i=1}^{20}\left(X_{i} C_{j}\right)+\left(X_{i} C_{l}\right)
$$

Where:

$X:$ is the number of trips

C: vehicle capacity

$i$ : store $1,2, \ldots, 20$

$j=12$ (van truck)

I= 14 (truck)

The vehicle capacity restriction was modeled according to Equation 4:

$$
X_{i j l} T C_{i} \leq T T O_{\text {torr }}
$$

Where:

$X_{j l}$ : is the number of trips to store $\mathrm{i}$ using the vehicle $\mathrm{j}$ or $\mathrm{l}$;

to: van truck

tr: Truck

Serving restrictions demand were also included, as shown in Equation 5:

$$
\left(X_{i} C_{j}\right)+\left(X_{i} C_{l}\right) \leq D P_{i}
$$

Where:

$D P:$ is pallets demand

It was also necessary to add an integer numbers restriction to variables $X$, because,fractional numbers would mean an incomplete trip with the vehicle. From 
INDEPENDENT JOURNAL OF MANAGEMENT \& PRODUCTION (IJM\&P)

http://www.ijmp.jor.br

v. 7, n. 5, Special Edition IFLOG 2015

ISSN: 2236-269X

DOI: 10.14807/ijmp.v7i5.454

the definition of the problem model under analysis, the next section presents data used as input for further analysis.

\subsection{Data collected in the company}

Initially, cycle times for each store were obtained, as shown in Table 1.

Table 1: Cycle time of the stores

\begin{tabular}{|c|c|c|c|c|c|}
\hline \multicolumn{6}{|c|}{ Time (Min) } \\
\hline Store & Charging & Route & Discharging & Returning & Cycle \\
\hline 1 & 55 & 24 & 26 & 20 & 125 \\
\hline 2 & 55 & 25 & 99 & 18 & 197 \\
\hline 3 & 55 & 42 & 61 & 38 & 196 \\
\hline 4 & 55 & 22 & 74 & 18 & 169 \\
\hline 5 & 55 & 15 & 34 & 14 & 118 \\
\hline 6 & 55 & 49 & 56 & 39 & 199 \\
\hline 7 & 55 & 30 & 56 & 25 & 166 \\
\hline 8 & 55 & 29 & 67 & 25 & 176 \\
\hline 9 & 55 & 40 & 65 & 37 & 197 \\
\hline 10 & 55 & 34 & 75 & 32 & 196 \\
\hline 11 & 55 & 43 & 69 & 35 & 202 \\
\hline 12 & 55 & 30 & 45 & 27 & 157 \\
\hline 13 & 55 & 33 & 36 & 29 & 153 \\
\hline 14 & 55 & 49 & 58 & 46 & 208 \\
\hline 15 & 55 & 53 & 27 & 44 & 179 \\
\hline 16 & 55 & 43 & 52 & 39 & 189 \\
\hline 17 & 55 & 33 & 61 & 36 & 185 \\
\hline 18 & 55 & 24 & 114 & 23 & 216 \\
\hline 19 & 55 & 46 & 85 & 42 & 228 \\
\hline 20 & 55 & 35 & 72 & 26 & 188 \\
\hline
\end{tabular}

The values in Table 1 were obtained by measuring charging average times, route, discharging and returning. These times were measured for three months, and summarized in the average shown in Table 1.

After having the measured cycle times, it was necessary to identify the operation times available. The drivers, who were outsourced, worked from Monday to Saturday, and each working week was equivalent to 44 hours. Thus, it has been 440 minutes of daily operation per vehicle, once considered the lunch time. Therefore, the total daily operating time of Trucks and Van trucks was obtained as shown in Equations 6 and 7. 
DOI: 10.14807/ijmp.v7i5.454

$$
\begin{aligned}
& \text { TTOtr }=10(500-60)=4400 \\
& \text { TTOto }=2(500-60)=880
\end{aligned}
$$

That is, the daily operation of the trucks is 4400 minutes while the van trucks use 880 minutes. Finally, it was stipulated the average demand for pallets to be sent per store, as shown in Table 2.

Table 2: Pallets demand to send to the store

\begin{tabular}{|r|c|c|c|c|c|}
\hline Store & Picking & Cross & Electro & Total & Demand \\
\hline 1 & 9,71 & 2,76 & 2,81 & 15,29 & 16,00 \\
\hline 2 & 18,24 & 2,76 & 2,00 & 23,00 & 23,00 \\
\hline 3 & 31,35 & 4,35 & 2,88 & 38,58 & 39,00 \\
\hline 4 & 20,65 & 3,29 & 2,06 & 26,00 & 26,00 \\
\hline 5 & 19,53 & 4,82 & 2,94 & 27,29 & 28,00 \\
\hline 6 & 41,41 & 3,94 & 3,12 & 48,47 & 49,00 \\
\hline 7 & 12,82 & 3,00 & 2,41 & 18,24 & 19,00 \\
\hline 8 & 21,50 & 3,56 & 3,36 & 28,42 & 29,00 \\
\hline 9 & 15,29 & 3,00 & 2,06 & 20,35 & 21,00 \\
\hline 10 & 17,35 & 2,94 & 2,50 & 22,79 & 23,00 \\
\hline 11 & 22,44 & 2,88 & 4,75 & 30,07 & 31,00 \\
\hline 12 & 6,14 & 2,24 & 1,92 & 10,30 & 11,00 \\
\hline 13 & 10,31 & 2,47 & 2,00 & 14,78 & 15,00 \\
\hline 14 & 12,73 & 2,53 & 2,29 & 17,55 & 18,00 \\
\hline 15 & 9,35 & 3,24 & 2,40 & 14,99 & 15,00 \\
\hline 16 & 9,15 & 2,82 & 2,20 & 14,18 & 15,00 \\
\hline 17 & 4,65 & 1,71 & 1,08 & 7,44 & 8 \\
\hline 18 & 7,69 & 2,24 & 2,09 & 12,01 & 13,00 \\
\hline 19 & 6,06 & 1,88 & 9,06 & 17,01 & 18,00 \\
\hline 20 & 6,82 & 1,76 & 1,20 & 9,79 & 10,00 \\
\hline \multicolumn{5}{|c|}{ Source: Designed by the study authors } \\
\hline
\end{tabular}

Table 2 values, similarly to those in Table 1 were measured for 3 months, being adopted pallets expedition mean of each sector for each store chain. Once these values had been added, it was finally obtained the average demand of pallets per store, after rounding up the total, because often there were incomplete pallets or that were not fully utilized, and these were also considered in the calculation.

The next section presents the results of the study. 
DOI: 10.14807/ijmp.v7i5.454

\subsection{Results}

After problem modelling and data preparation shown in the previous sections, SOLVER was conducted on a computer with Intel Core i5 processor with 4 Giga RAM. The results obtained are presented in Table 3.

The SOLVER showed an optimal solution where 342 pallets were sent from a total of 427 pallets, remaining 85 pallets to be sent. However, this amount would be impractical to deliver because they are settings that would not meet the vehicle restriction in traveling at full charge capacity, as shown in Table 4.

Table 3: Pallets to send at the end of the day

\begin{tabular}{|l|l|}
\hline Store & Pallets to send \\
\hline 1 & 2 \\
\hline 2 & 9 \\
\hline 3 & 1 \\
\hline 4 & 0 \\
\hline 5 & 0 \\
\hline 6 & 7 \\
\hline 7 & 5 \\
\hline 8 & 1 \\
\hline 9 & 7 \\
\hline 10 & 9 \\
\hline 11 & 3 \\
\hline 12 & 11 \\
\hline 13 & 1 \\
\hline 14 & 4 \\
\hline 15 & 1 \\
\hline 16 & 1 \\
\hline 17 & 8 \\
\hline 18 & 1 \\
\hline 19 & 4 \\
\hline 20 & 10 \\
\hline Total & 85 \\
\hline
\end{tabular} Source: Designed by the study authors.

Concerning the cycle times, it was quantified the use 3792 minutes of the trucks and 777 minutes of the van trucks. This represents $86.18 \%$ and $88.30 \%$ of the vehicles use in operation, respectively. While the trucks traveled 21 times, the van trucks traveled 4 . The stores which most used this system were the units $6,3: 11$, with a use of $13.07 \%, 12.87 \%$ and $8.84 \%$ respectively. Table 4 shows the resolution obtained. 
DOI: 10.14807/ijmp.v7i5.454

Table 4: SOLVER resolution

\begin{tabular}{|c|c|c|c|c|c|c|c|c|c|c|c|c|}
\hline \multicolumn{2}{|c|}{ Demand } & \multicolumn{2}{|c|}{ Variables } & \multicolumn{2}{|c|}{$\begin{array}{l}\text { Vehicle } \\
\text { capacity }\end{array}$} & \multicolumn{3}{|c|}{ Pallets sent } & \multirow{2}{*}{$\begin{array}{l}\text { Cycle } \\
\text { time }\end{array}$} & \multicolumn{3}{|c|}{ Route } \\
\hline Store & Total & Truck & $\begin{array}{l}\text { Van } \\
\text { Truck }\end{array}$ & Truck & $\begin{array}{l}\text { Van } \\
\text { Truck }\end{array}$ & Truck & \begin{tabular}{l|} 
Van \\
Truck
\end{tabular} & Total & & Truck & \begin{tabular}{|l|} 
Van \\
Truck
\end{tabular} & Total \\
\hline 1 & 16 & 1 & 0 & 14 & 12 & 14 & 0 & 14 & 125 & 125 & 0 & 125 \\
\hline 2 & 23 & 1 & 0 & 14 & 12 & 14 & 0 & 14 & 197 & 197 & 0 & 197 \\
\hline 3 & 39 & 1 & 2 & 14 & 12 & 14 & 24 & 38 & 196 & 196 & 392 & 588 \\
\hline 4 & 26 & 1 & 1 & 14 & 12 & 14 & 12 & 26 & 169 & 169 & 169 & 338 \\
\hline 5 & 28 & 2 & 0 & 14 & 12 & 28 & 0 & 28 & 118 & 236 & 0 & 236 \\
\hline 6 & 49 & 3 & 0 & 14 & 12 & 42 & 0 & 42 & 199 & 597 & 0 & 597 \\
\hline 7 & 19 & 1 & 0 & 14 & 12 & 14 & 0 & 14 & 166 & 166 & 0 & 166 \\
\hline 8 & 29 & 2 & 0 & 14 & 12 & 28 & 0 & 28 & 176 & 352 & 0 & 352 \\
\hline 9 & 21 & 1 & 0 & 14 & 12 & 14 & 0 & 14 & 197 & 197 & 0 & 197 \\
\hline 10 & 23 & 1 & 0 & 14 & 12 & 14 & 0 & 14 & 196 & 196 & 0 & 196 \\
\hline 11 & 31 & 2 & 0 & 14 & 12 & 28 & 0 & 28 & 202 & 404 & 0 & 404 \\
\hline 12 & 11 & 0 & 0 & 14 & 12 & 0 & 0 & 0 & 157 & 0 & 0 & 0 \\
\hline 13 & 15 & 1 & 0 & 14 & 12 & 14 & 0 & 14 & 153 & 153 & 0 & 153 \\
\hline 14 & 18 & 1 & 0 & 14 & 12 & 14 & 0 & 14 & 208 & 208 & 0 & 208 \\
\hline 15 & 15 & 1 & 0 & 14 & 12 & 14 & 0 & 14 & 179 & 179 & 0 & 179 \\
\hline 16 & 15 & 1 & 0 & 14 & 12 & 14 & 0 & 14 & 189 & 189 & 0 & 189 \\
\hline 17 & 8 & 0 & 0 & 14 & 12 & 0 & 0 & 0 & 185 & 0 & 0 & 0 \\
\hline 18 & 13 & 0 & 1 & 14 & 12 & 0 & 12 & 12 & 216 & 0 & 216 & 216 \\
\hline 19 & 18 & 1 & 0 & 14 & 12 & 14 & 0 & 14 & 228 & 228 & 0 & 228 \\
\hline 20 & 10 & 0 & 0 & 14 & 12 & 0 & 0 & 0 & 188 & 0 & 0 & 0 \\
\hline
\end{tabular}

As it can be seen in Table 4, the proposed model sent 427 pallets to the stores, 26 pallets more than the operation performed on the DC in question. This optimization was mainly given because developers were sending suboptimal amounts, despite already knowing the total demand for pallets to be sent. This occurs because of the way the expedition was operated, in view of the pallets were randomly sent, that is, the easiest charge to be grouped together for charging the vehicle was the one chosen.

The next section presents the final considerations.

\section{FINAL CONSIDERATIONS}

It is concluded that the hypothesis was not rejected, ie the linear programming tool was suitable for the expedition planning activities in the case analyzed. In this particular study, the model allowed to suggest enlarging the use of vehicles, the demand absorbed by each store and identified important points, such as the fact that 
DOI: 10.14807/ijmp.v7i5.454

the pallets demand and DC expedition capacity are aligned, having no fleet sizing problems nor installations.

The model designed made possible to obtain information on how to allocate charges for expedition before operationalizing activities, allowing to plan the operation more efficiently based on data collected in the company. It was possible to increase the number of pallets sent to stores, when compared with the historical decisions made by the company.

The Excel SOLVER, which was the tool used for the LP modeling problem in this study was an appropriate tool for the development and operationalizing of the proposed model, proving useful for optimizing development with simplified models.

It is important to mention that, in order to obtain results that actually contribute to an improvement in a company's expedition planning, it is necessary that the data collected fairly represent the company's reality, that perhaps it is a question involving more difficult aspects than modeling problem itself.

Regarding the limitations this study shows, one of them would be not considering the operation after the expedition, which is transporting DC materials to stores. Future studies may expand the analysis undertaken in this study and consider this operation.

\section{REFERENCES}

ANDERSON, D. R.; SWEENEY, D. J.; WILLIAMS, T. A. (2007) Estatística Aplicada a Administração e Economia. 2a . Ed. São Paulo: Pioneira Thomson Learning.

ANDRADE, E. L. (2009) Introdução à pesquisa operacional: métodos e modelos para a análise de decisões. Rio de Janeiro: LTC.

ARENALES, M.; ARMENTANO, V.; MORABITO, R.; YANASSE, H. (2007) Pesquisa Operacional. Rio de Janeiro: Campus/Elsevier.

BARCELOS, B. O.; EVANGELISTA, M. L. S.; SEGATTO, S. S. (2012) A importância e a aplicação da pesquisa operacional nos Cursos de graduação em Administração. RACE - Revista de Administração, Contabilidade e Economia, [S.I.], v. 11, n. 2, p. 381-405.

BROWNE, M., SWEET, M., WOODBUM, A. e ALLEN, J. (2005) Urban freight consolidation centers. Documento de Trabalho - University of Westminster, London.

CANAVARRO, C. (2005) Apostila de programação linear: problema de transporte. Instituto Politécnico de Castelo Branco. 
CASTRO, N. (2013) Mensuração de externalidades do transporte de carga brasileiro. Journal of Transport Literature, vol. 7, n. 1, pp.163-181.

COSTA, A. P. R. et al. (2014) Otimização de custos do transporte público urbano: comprar ou vender um ônibus usado? Revista de Gestão, Finanças e Contabilidade, v. 4, n. 2, p. 73-92.

DANTZIG, G. (1963) Linear programming and extensions. Princeton University Press e RAND Corporation.

DANTZIG, G. (1953) Notes on linear programming. RAND Corporation.

HILLIER, F. S; LIEBERMAN, G. J. (2010) Introdução à pesquisa operacional. 8 ed. Rio de Janeiro: AAMGH.

KARSU, Ö.; MORTON, A. (2015) Inequity averse optimisation in operational research. European Journal of Operational Research.

LANCHTERMACHER, G. (2007) Pesquisa Operacional na Tomada de Decisões , 3 ed, Rio de Janeiro: Campus.

LAPORTE, G. (1992) The vehicle routing problem: An overview of exact and approximate algorithms. European Journal of Operational Research, Elsevier, v. 59, n. 3, p. 345-358.

MARINS, F. A. S. (2011) Introdução a pesquisa operacional. São Paulo: Cultura Acadêmica: Universidade Estadual Paulista, Pró-reitora de Graduação, 176 p.

OLIVEIRA, A. L. R. (2014) Otimização de recebimento e distribuição em unidades armazenadoras de soja. Dissertação de Mestrado - PUC/RIO.

OLIVEIRA, L. K. (2014) Diagnóstico das vagas de carga e descarga para a distribuição urbana de mercadorias: um estudo de caso em Belo Horizonte. J. Transp. Lit. [online]. vol.8, n.1, pp. 178-209.

Panorama llos. (2015) Custos logísticos no Brasil. Disponível em:

<http://www.ilos.com.br/ilos_2014/wpontent/uploads/PANORAMAS/PANORAMA_bro chura_custos.pdf>. Accessed in: 06/10/2015.

PINHEIRO, D. H. (2015) Desenvolvimento de um modelo de otimização de consumo de combustível para o problema de roteamento de veículos capacitados. Disponível em: <http://repositorio.ufla.br/jspui/handle/1/5213> Accessed in: 05/24/2015.

RAGSDALE, C. T. (2007) Spreadsheet Modeling and Decision Analysis: A Practical Introduction to Management Science. 5 ed. Virginia: South Western College.

RAYMUNDO, E. A.; GONÇALVES, L. W. N.; RIBEIRO, N. S. (2015) Pesquisa operacional na tomada de decisão: modelo de otimização de produção e maximização do lucro. Revista de Gestão\&Tecnologia, v. 3, n. 1.

RONCARI, G. E.; JUNIOR, O. D. (2012) OTIMIZAÇÃO DO TRANSPORTE E LOGÍSTICA DE MATERIAIS. Tekhne e Logos, v. 3, n. 1.

SANTOS, R. F; JUNIOR, E. C. S.; BOUZADA, M. A. C. (2012) A aplicação da programação inteira na solução logística do transporte de carga: o solver e suas limitações na busca pela solução ótima. Revista Produção Online, v. 12, n. 1, p. 185-204. 
INDEPENDENT JOURNAL OF MANAGEMENT \& PRODUCTION (IJM\&P)

http://www.ijmp.jor.br

v. 7, n. 5, Special Edition IFLOG 2015

ISSN: 2236-269X

DOI: 10.14807/ijmp.v7i5.454

VANDERBEI ,R. (2008) Linear Programming. Foundations and Extensions .3 ed, Springer.

YIN, R. K. (2010) Estudo de caso: planejamento e métodos. 4.ed. 248p. Porto Alegre: Bookman. 